\title{
PHYSICOCHEMICAL CHARACTERISTICS OF SERBIAN HONEYDEW HONEY
}

\author{
Milica Živkov Baloš ${ }^{*}$, Sandra Jakšić ${ }^{1}$, Nenad Popov ${ }^{1}$, \\ Suzana Vidaković Knežević́ ${ }^{1}$, Dragana Ljubojević Pelić ${ }^{1}$, \\ Miloš Pelić ${ }^{1}$, Vladimir Polaček ${ }^{1}$, Dubravka Milanov ${ }^{1}$ \\ ${ }^{1}$ Scientific Veterinary Institute „Novi Sad“, Novi Sad, Republic Serbia
}

\section{Abstract}

The aim of this study was to investigate the composition and quality of Serbian honeydew honey. For this purpose, the physicochemical characteristics of 14 honeydew samples were analyzed. The physicochemical characteristics of all honeydew honeys from Serbia analyzed in this research can be considered to be within the parameters prescribed for honeydew in general. The sum value of glucose and fructose, the content of sucrose, water, hydroxymethylfurfural, acidity, and diastase activity were in line with European and national regulations for honey, for all investigated honeydew samples. Out of a total of 14 tested honey samples, 1 sample did not comply with the national regulations for honey regarding electrical conductivity. According to our results, in most of investigated samples the fructose/glucose $(\mathrm{F} / \mathrm{G})$ ratio was greater than 1.11 and glucose/water $(\mathrm{G} / \mathrm{W})$ ratio was close to 2 . This means that they can be categorized as medium-crystallizing honeys. The results obtained in this study indicate excellent quality, absence of undesirable fermentation, acceptable freshness and proper manipulation of Serbian honeydews.

Key words: honeydew honey, physicochemical characteristics

\footnotetext{
${ }^{1 *}$ Corresponding author email: milica@niv.ns.ac.rs
} 


\title{
FIZIČKO-HEMIJSKE KARAKTERISTIKE MEDLJIKOVCA POREKLOM IZ REPUBLIKE SRBIJE
}

\author{
Milica Živkov Baloš1, Sandra Jakšić ${ }^{1}$, Nenad Popov ${ }^{1}$, \\ Suzana Vidaković Knežević ${ }^{1}$, Dragana Ljubojević Pelić ${ }^{1}$, \\ Miloš Pelić ${ }^{1}$, Vladimir Polaček ${ }^{1}$, Dubravka Milanov ${ }^{1}$
}

${ }^{1}$ Naučni Institit za veterinarstvo “Novi Sad”, Novi Sad, Republika Srbija

\section{Kratak sadržaj}

U ovom radu ispitivan je sastav i kvalitet srpskog medljikovca (šumskog meda). Rezultati ispitivanja fizičko-hemijskih karakteristika medljikovca iz Srbije nalaze se u granicama očekivanih vrednosti za medljikovac. Vrednosti dobijene za sadržaj redukujućuh šećera (glukoza i fruktoza), saharoze, vode, hidroksimetilfurfurola, kao i kiselost i aktivnosti dijastaze su u skladu sa evropskim i nacionalnim propisima koji se odnose na kvalitet meda. Od ukupno 14 ispitanih uzoraka medljikovca, 1 uzorak nije odgovarao odredbama propisa u pogledu električne provodljivosti. Prema rezultatima ispitivanja, $u$ većini ispitivanih uzoraka odnos $F / G$ je bio veći od 1,11, a odnos G/V bio je blizu 2. Na osnovu ovih rezultata, medljikovac se može okarakterisati kao med sa srednjom brzinom kristalizacije. Rezultati dobijeni u našem istraživanju ukazuju na odličan kvalitet, odsustvo neželjene fermentacije, prihvatljivu svežinu i pravilnu manipulaciju srpskim medljikovcem.

Ključne reči: medljikovac, fizičko-hemijske karakteristike

\section{Introduction}

Honeydew is honey produced by bees (Apis mellifera) from secretions of living parts of plants or excretions of plant-sucking insects (European Commission, 2002). Secretions of living parts of plants are sweet substances that appear periodically on the leaves of some plants, most commonly on fir, pine, spruce, willow, oak, soft chestnut and other evergreen and deciduous trees (Primorac et el., 2009; Vasić et al. 2019).

The interest in honeydew has increased because of its nutritional, sensorial and potential therapeutic properties (Sergalio et al., 2019). Honeydew is a distinctive honey compared to blossom honey since it usually has higher electrical conductivity, $\mathrm{pH}$ values, ashes, higher content of disaccharides, trisaccharides, and lower content of monosaccharides (Sergalio et al., 2019; Živkov Baloš et al., 2018, 2019a). Darker color and different sensory features compared 
to blossom honey are also the characteristics of this type of honey (Escuerdo et al., 2013; Flores et al., 2015; Živkov Baloš et al., 2019b). Numerous studies have established that honeydew contains a number of bioactive compounds, such as proteins, amino acids and phenolics (Bogdanov et al., 2004; Escuerdo et al., 2013; Silva et al., 2018; Vasić et al., 2019), compared to other types of honey, which classifies it as health-promoting food.

Basically, honey is a concentrated water solution of fructose and glucose, with small amounts of various complex sugars (Escuredo et al., 2014; ValdésSilverio et al., 2018). Fructose and glucose are present in nectar or in the carbohydrate excretion of insects that suck the fluid from the phloem (Lazarević et al., 2017). As a result of high concentration of sugar, honey crystallizes over time. Some components of honey, such as other carbohydrates, pollen grains, air bubbles, and particles can have an impact on the crystallization of honey. Fructose/glucose $(\mathrm{G} / \mathrm{F})$ ratio and glucose/water $(\mathrm{G} / \mathrm{W})$ ratio can be used to estimate the rate of honey crystallization. Generally, honeys with low G/W and F/G ratio do not crystallize easily (Escuredo et al., 2014).

Crystallization of honey is an undesirable process. During the crystallization changes occur in the textural properties, making honey less appealing to consumers, who prefer liquid and transparent product (Kabbani et al., 2011). Crystallization of honey affects the processing of honey during extraction, filtration, mixing and bottling (Dobre et al., 2012; Laos et al., 2011).

Honeydew honey is a natural product with complex composition, which depends on bee species, geographical region, available floral source and storage conditions (Karabagias et al., 2014). Considering all the factors mentioned above and the number of possible floral sources in particular, it is understandable that no two honeys are the same (Kirs et al., 2011). Honeydew physicochemical quality criteria are well specified by the European Legislation (European Commission, 2002) and the regulation concerning the quality of honey in the Republic of Serbia (Official Gazette RS, 101/2015). The major criteria for honey in both of those standards are sugar content (sucrose and sum of fructose and glucose), moisture content, water-insoluble content, electrical conductivity, free acidity, diastase activity and hydroxymethylfurfural (HMF) content.

The aim of this study was to investigate the composition of Serbian honeydew honey, in order to obtain the information about the honey quality, and gain an insight into its nutritional suitability.

\section{MATERIAL AND METHODS}

A total of 14 honeydew samples were collected from beekeepers at different regions of Serbia. All collected samples were in their original packaging 
and transferred to the laboratory of Scientific Veterinary Institute "Novi Sad" for examination. Manufacturers used field observations for botanical origin determination. Our research included only the samples with confirmed botanical origin stated on the manufacturing specification label. All the selected samples were produced by Apis mellifera. Honey analyses were carried out immediately after sampling. All samples were analyzed in duplicate by methods prescribed in Harmonised methods of the International Honey Commission Methods (2009).

\section{Water content analysis}

Water content was determined by refractometry, measuring the refractive index (RI) using a standard model Abbetype refractometer at $20^{\circ} \mathrm{C}$. Water content (\%) was then obtained from the Chataway table.

\section{Electrical conductivity}

Electrical conductivity was measured at $20^{\circ} \mathrm{C}$ in solutions of honey samples (20.0 g dry matter of honey in volume solution in $100 \mathrm{ml}$ distilled water) using a conductometer Crison (Type Basic 30).

\section{Free acidity}

The acidity of honey was determined by volumetric method. Ten grams of honey was dissolved in $75 \mathrm{ml}$ of water and solution was titrated with $0.1 \mathrm{M}$ $\mathrm{NaOH}$ to $\mathrm{pH} 8.30$. Acidity is expressed in milliequivalents $/ \mathrm{kg}$ honey $(\mathrm{mEq} / \mathrm{kg})$.

\section{Water-insoluble matter}

Insoluble matter was determined by gravimetric method. The insoluble matter was collected on filter of specified pore size by rinsing with warm water. Dried residues $\left(135^{\circ} \mathrm{C}\right)$ were weighed until constant weight was obtained.

\section{Hydroxymethylfurfural}

HMF was determined by an HPLC Dionex UltiMate 3000 Series system with UV detection (Thermo Scientific, Germany). Honey sample ( $1 \mathrm{~g}$ ) was dissolved in $25 \mathrm{~mL}$ of water, filtered through a $0.45 \mu \mathrm{m}$ nylon filter and injected $(10 \mu \mathrm{l})$ into the HPLC system. The HPLC column was 150x3 mm Hyperilsil GOLD, with particle size of $3 \mu \mathrm{m}$. The mobile phase was methanol: water $(10: 90, \mathrm{v} / \mathrm{v})$, at flow rate of $1 \mathrm{~mL} / \mathrm{min}$. All measurements were conducted at room temperature. The system was controlled by Chromeleon ${ }^{\oplus} 7$ software (Thermo Scientific, Germany).

The external calibration curves produced by standard solutions were used to quantify the amount of HMF in the samples. 


\section{Sugar Composition determination}

The sugar composition (fructose, glucose, sucrose) was determined by an HPLC Dionex UltiMate 3000 Series system (Thermo Scientific, Germany) equipped with a refractive index detector RefractoMax521 (ERC Inc, Japan) at $35^{\circ} \mathrm{C}$. Honey sample $(1 \mathrm{~g})$ was dissolved in $25 \mathrm{~mL} 25 \%$ methanol, filtered through a $0.22 \mu \mathrm{m}$ nylon filter and injected $(5 \mu \mathrm{l})$ into the HPLC system. The HPLC column was Hypersil GOLD Amino 150x3 mm (particle size $3 \mu \mathrm{m}$ ), fitted with a guard column Hypersil GOLD Amino 10x3 mm (particle size 3 $\mu \mathrm{m})$. The mobile phase was acetonitrile: water $(8: 2, \mathrm{v} / \mathrm{v})$ filtered through 0.22 $\mu \mathrm{m}$ membrane filter, at a flow rate of $1 \mathrm{~mL} / \mathrm{min}$. All measurements were performed at room temperature. The system was controlled by Chromeleon ${ }^{\bullet} 7$ software (Thermo Scientific, Germany). The external calibration curves produced by standard solutions were used to quantify the amount of sugars in the samples. Honey sugars were identified and quantified by comparing their retention times and peak areas with those of standard sugar solutions.

\section{Diastase activity}

Diastase activity was determined by spectrophotometric method (Megazyme International Ireland, 2014). Two grams $(2.00 \mathrm{~g})$ of sample were dissolved in sodium maleate buffer and adjusted volume to the mark of volumetric flask with water. Amylazyme tablets (Megazyme International, Ireland) were added to buffer solution. In the presence of $\alpha$-amylase, the substrate is hydrolysed and soluble dyed products are released. The reaction was terminated and, following the filtration, the absorbance of the filtrate is measured at $590 \mathrm{~nm}$. The absorbance is directly proportional to the diastase activity of the sample. The diastase activity is calculated as diastase number (DN).

\section{Statistical analysis}

Statistical analysis was performed by the PAST software package, version 2.12 , Oslo, Norway. The data were grouped according to the samples of honeydew and presented as mean, standard deviation, minimum, maximum values, and coefficient of variation.

\section{Results}

The results of physicochemical analysis of Serbian honeydew are shown in Tables 1 and 2. The water content in all investigated honeydew samples was below $20 \%$, which is the maximum permissible level set by national regulations for honey (Official Gazette, 101/2015). 
The results of sugar profile analysis by HPLC-RI are shown in Table 1. Our study revealed that in all examined honeydew samples, the percentage of fructose and glucose ranged from 28.51 to 38.83 and from 24.92 to $34.09 \%$, respectively. The sum value of glucose and fructose was in line with European and national regulations (EU, 2002; Official Gazette RS, 101/2015) with the value of over $45 \mathrm{~g} / 100 \mathrm{~g}$ for all honeydew samples. Sucrose content in all investigated honey samples was below $5 \mathrm{~g} / \mathrm{kg}$ honey, which is the maximum permissible level set by the European Legislation (EU, 2002) and national regulations for honey (Official Gazette RS, 101/2015). In 13 out of the total of 14 investigated samples (93\%), sucrose content was below the detection limit of the applied method. Detection limit of the applied method is $0.25 \%$. The $\mathrm{F} / \mathrm{G}$ ratio and $\mathrm{G} / \mathrm{W}$ ratios were calculated for all samples of honeydew. The mean $\mathrm{F} / \mathrm{G}$ ratio was 1.22 and ranged from 1.06 to 1.50 . The mean $\mathrm{G} / \mathrm{W}$ ratio was 1.89 and ranged from 1.50 to 2.32 .

Table 1. Moisture content and carbohydrate concentrations of honeydew samples

\begin{tabular}{|c|c|c|c|c|c|c|c|}
\hline Sample & $\begin{array}{c}\text { Water }^{1} \\
(\%)\end{array}$ & $\begin{array}{c}\text { Fructose }^{2} \\
(\%)\end{array}$ & $\begin{array}{c}\text { Glucose }^{3} \\
(\%)\end{array}$ & $\begin{array}{c}\text { Sucrose } \\
(\%)\end{array}$ & $\begin{array}{c}F+G \\
(\%)\end{array}$ & $\begin{array}{c}\text { Ratio } \\
\text { F/G }\end{array}$ & $\begin{array}{l}\text { Ratio } \\
\text { G/W }\end{array}$ \\
\hline 1 & 17.0 & 33.99 & 30.37 & n.d. ${ }^{4}$ & 64.36 & 1.12 & 1.79 \\
\hline 2 & 15.4 & 38.32 & 34.09 & n.d. & 72.41 & 1.12 & 2.21 \\
\hline 3 & 16.6 & 36.02 & 24.98 & n.d. & 61.00 & 1.44 & 1.50 \\
\hline 4 & 15.8 & 37.18 & 24.92 & n.d. & 62.10 & 1.49 & 1.58 \\
\hline 5 & 15.4 & 37.57 & 25.01 & n.d. & 62.58 & 1.50 & 1.62 \\
\hline 6 & 14.2 & 35.76 & 29.44 & n.d. & 65.20 & 1.21 & 2.07 \\
\hline 7 & 16.4 & 31.94 & 26.32 & n.d. & 58.26 & 1.21 & 1.60 \\
\hline 8 & 14.4 & 28.91 & 27.18 & n.d. & 56.09 & 1.06 & 1.89 \\
\hline 9 & 13.6 & 34.70 & 31.51 & n.d. & 66.21 & 1.10 & 2.32 \\
\hline 10 & 16.2 & 36.10 & 31.74 & n.d. & 67.84 & 1.14 & 1.96 \\
\hline 11 & 16.6 & 36.03 & 31.78 & n.d. & 67.81 & 1.13 & 1.91 \\
\hline 12 & 14.8 & 36.31 & 28.48 & n.d. & 64.79 & 1.27 & 1.92 \\
\hline 13 & 14.1 & 34.14 & 31.73 & 0.30 & 65.87 & 1.08 & 2.25 \\
\hline 14 & 18.2 & 38.83 & 33.41 & n.d. & 72.24 & 1.16 & 1.84 \\
\hline Minimum & 13.6 & 28.91 & 24.92 & $<0.25$ & 56.09 & 1.06 & 1.50 \\
\hline Maximum & 18.2 & 38.83 & 34.09 & 0.30 & 72.41 & 1.50 & 2.32 \\
\hline STDEV $^{5}$ & 1.3 & 2.61 & 3.21 & I & 4.64 & 0.15 & 0.26 \\
\hline Mean & 15.6 & 35.41 & 29.35 & $<0.25$ & 64.77 & 1.22 & 1.89 \\
\hline $\mathrm{CV}(\%)^{6}$ & 8.35 & 7.37 & 10.94 & & 7.17 & 12.51 & 13.67 \\
\hline
\end{tabular}

${ }^{1} \mathrm{~W}$ - Water. ${ }^{2} \mathrm{~F}$ - Fructose. ${ }^{3} \mathrm{G}$ - Glucose. n.d. ${ }^{4}$ - unquantifiable value (less than detection limit); $\mathrm{STDEV}^{5}$ - standard deviation; $\mathrm{CV}^{6}$ - coefficient of variation 
In accordance with the regulation concerning the quality of honey in the Republic of Serbia (Official Gazette, 101/2015), minimum electrical conductivity in honeydew put in the market is fixed to $0.8 \mathrm{mS} / \mathrm{cm}$. The values of electrical conductivity in the investigated honeydew samples were between 0.61 and $1.99 \mathrm{~ms} / \mathrm{cm}$. Out of a total of 14 tested honey samples, 1 sample (No. 11) did not comply with the national regulations for honey.

Maximum value of free acidity in all types of honey (except in baker's honey) was $50 \mathrm{mEq} / \mathrm{kg}$, as is set by regulation (Official Gazette, 101/2015). Free acidity in all tested honeydew samples was below $50 \mathrm{mEq} / \mathrm{kg}$. These data indicate the absence of undesirable fermentation. The mean acidity value in the investigated samples was $21.29 \mathrm{mEq} / \mathrm{kg}$.

Table 2. Electrical conductivity, free acidity, 5-HMF and diastase activity in honeydew samples

\begin{tabular}{|c|c|c|c|c|}
\hline Sample & $\begin{array}{l}\text { Electrical } \\
\text { conductivity } \\
\left(\mathrm{mS} \mathrm{cm}^{-1}\right)\end{array}$ & $\begin{array}{l}\text { Free acidity } \\
(\text { meq kg })^{-1}\end{array}$ & $\begin{array}{c}5-\mathrm{HMF}^{1} \\
\left(\mathrm{mg} \mathrm{kg}^{-1}\right)\end{array}$ & $\begin{array}{c}\text { Diastase } \\
\text { (DN) }\end{array}$ \\
\hline 1 & 1.22 & 9.6 & 5.21 & 25.16 \\
\hline 2 & 0.87 & 7.4 & 0.50 & 17.19 \\
\hline 3 & 0.88 & 5.4 & 11.72 & 17.74 \\
\hline 4 & 0.82 & 4.6 & 1.35 & 13.43 \\
\hline 5 & 0.89 & 4.6 & 0.81 & 18.64 \\
\hline 6 & 1.15 & 30.0 & 1.85 & 22.12 \\
\hline 7 & 1.60 & 48.4 & 6.55 & 12.08 \\
\hline 8 & 1.85 & 44.0 & 1.69 & 20.87 \\
\hline 9 & 1.15 & 33.0 & 2.77 & 16.23 \\
\hline 10 & 1.55 & 29.0 & 11.20 & 14.25 \\
\hline 11 & 0.61 & 18.0 & 18.08 & 19.01 \\
\hline 12 & 1.33 & 15.5 & 1.48 & 28.55 \\
\hline 13 & 1.99 & 21.5 & 1.41 & 23.33 \\
\hline 14 & 1.15 & 27.0 & 26.01 & 26.47 \\
\hline Minimum & 0.61 & 4.6 & 0.50 & 12.08 \\
\hline Maximum & 1.99 & 48.40 & 26.01 & 28.55 \\
\hline STDEV & 0.41 & 14.52 & 7.70 & 5.00 \\
\hline Mean & 1.22 & 21.29 & 6.47 & 18.43 \\
\hline CV (\%) & 33.37 & 68.20 & 118.92 & 25.46 \\
\hline
\end{tabular}

5-HMF ${ }^{1}$ : 5-hydroxymethylfurfural 
The regulation concerning the quality of honey in the Republic of Serbia established the maximum 5-HMF content $(40 \mathrm{mg} / \mathrm{kg}$ ) and minimum diastase activity $(8 \mathrm{DN})$. Generally, all tested samples were in compliance with the provisions of the Regulations regarding the content of 5-HMF and diastase activity. Mean 5-HMF content in investigated honeydew samples was $6.47 \mathrm{mg} / \mathrm{kg}$, with the range 0.50 to $26.01 \mathrm{mg} / \mathrm{kg}$. Minimum value of diastase activity was 12.08 DN and mean activity was $18.43 \mathrm{DN}$ (Table 2).

\section{Discussion}

Honey is a highly viscous solution of sugars, dominantly glucose and fructose in about equal concentrations (Venir et al., 2010). The most prevalent sugar in honeydew is fructose, followed by glucose and sucrose. These results are in accordance with other literature data (Kirs et al., 2011; Kivrak et al., 2017; Sousa et al., 2016; Sergalio et al., 2019; Seijo et al., 2019). In general, the glucose content was lower than the fructose content, which indicated the natural feeding of bee colonies and confirmed the high quality of the examined honeydew honeys. Sucrose content can also be used as an indicator of artificial feeding of honeybees, if beekeepers overfeed the bees with sugar during the spring. High concentration of sucrose means an early harvest of honey (Ouchemoukh et al., 2007; Pasias et al., 2017; Saxena et al., 2010).

F/G and G/W ratios are important parameters for predicting the crystallization tendency of honey. Fructose/glucose ratio shows the degree of honey crystallization, because glucose is less water soluble than fructose (Laos et al., 2011). Honey samples in which $F / G$ ratio is greater than 1.33 do not crystallize for a long period of time. If the F/G ratio is less than 1.11, honey crystallizes quickly (Escuerdo et al., 2014). Crystallization process is slower or null when $\mathrm{G} / \mathrm{W}$ ratio is less than 1.7, and it is faster when the ratio is higher than 2 (Dobre et al., 2012) or 2.10 (Venir et al., 2010). According to our results (Table 1), in most of investigated samples, F/G ratio was greater than 1.11 and $\mathrm{G} / \mathrm{W}$ ratio was close to 2, so they can be categorized as medium-crystallizing honey.

Water is the second largest component of honeydew. Honey moisture depends on the production season, floral source, abundance of nectar flow, soil, ventilation of beehives, colony strength, meteorological conditions in the area of honey production (primarily air humidity), and maturation and honey harvest time (Escuerdo et al., 2014; Kirs et al., 2011; Lazarević et al., 2017; Sousa et al., 2016; Živkov Baloš et al., 2019b). Moisture significantly affects the physical properties of honey such as crystallization, viscosity, and rheological behaviour. Although there are differences in moisture content, it can be assumed 
that the tested honeydews had adequate maturity since moisture was generally lower than the maximum permissible value (20\%). As shown in Table 1., moisture of honeydew samples is fairly homogeneous, and this parameter is characterized by a low coefficient of variation.

The electrical conductivity is often used in routine quality control of honey. The conductivity is related to the concentration of soluble minerals, organic acids and proteins. It is a useful tool for distinguishing honeys of different botanical origin. Storage time can also affect the electrical conductivity of honey. The most adequate parameters for distinguishing honeys of different geographical origin are those which described the patterns of $\mathrm{pH}$ and electrical conductivity with changes of honey concentration (Acquarone et al., 2007). Honeydew honey is characterized by higher electrical conductivity than blossom honeys, which is a good parameter to distinguish between the two types of honey. The values lower than $0.8 \mathrm{mS} / \mathrm{cm}$ may indicate adulteration or mixtures with other types of honey (Sergalio et al., 2019).

Free acidity in the examined samples ranged between 4.6 and $48.4 \mathrm{mEq} /$ $\mathrm{kg}(\mathrm{CV}=68.2 \%)$ (Table 2$)$. The acidity of honey is caused by organic acids (tartaric, citric, oxalic, acetic, etc.), nectar or bee secretions (Yadata, 2014). The acidity value varies depending on the floral source and bee species (Sousa et al., 2016). Our earlier results (Živkov Baloš et al., 2018) demonstrated high acidity of forest honey, as compared with other honey types. These results were also reported by Bergamo et al. (2019) and Primorac et al. (2009). The natural acidity of honey can be increased by the storage and ripening of honey, as well as during honey fermentation. Honey adulterated with sugar syrup has acidity lower than 1 , while honey that is adulterated with invert sugar has a pronounced high acidity (Yadata, 2014).

5 -Hydroxymethylfurfural is formed as an intermediate product in the Maillard reaction from the direct dehydration of sugars under acidic conditions during thermal processing of foods (Pasias et al., 2017). This compound is formed slowly and naturally during honey storage. Thus, it is considered an indicator of honey freshness (Serglaio et al., 2019). Diastase activity is closely related to 5-HMF. This parameter is sensitive to heat and long storage period. Diastase activity signifies a possible overheating of honey, above $60^{\circ} \mathrm{C}$, as well as prolonged storage (Bergamo et al., 2019). Considering the 5-HMF content and diastase activity found for investigated honeydew honeys, all samples were in accordance with the established limits. These results indicate acceptable freshness and proper manipulation of honeydews. 


\section{Conclusion}

The physicochemical characteristics of all honeydew honeys from Serbia analysed in this research are within the parameters expected for honeydew in general. Additionally, it can be concluded that Serbian honeydew is characterized by good quality as honey samples were within limits established by the European and national Legislation.

Therefore, further research on honeydew physicochemical and therapeutic properties is required to confirm the quality and authenticity of this product and for better understanding of the value of this honey.

\section{Author's Contribution:}

M.Ž.B. drafted the manuscript and made substantial contributions to the basic idea; S.J. carried out the HPLC analysis and was involved in drafting of the manuscript; N.P. carried out other physicochemical analysis and performed statistical analysis; D.LJ.P and S.V.K. were involved in drafting of the manuscript; M.P. collected the data; V.P. and D.M. revised the manuscript.

\section{Competing interest}

Authors declared no conflict of interests regarding the present paper.

\section{ACKNOWLEDGEMENT}

This paper is a result of the research within the projects TR 31071 and TR 31084 financed by the Ministry of Education, Science and Technological Development, Republic of Serbia.

\section{REFERENCES}

1. Acquarone C., Buera P., Elizalde B. 2007. Pattern of $\mathrm{pH}$ and electric conductivity upon honey dilution as a complementary tool for discriminating geographical origin of honeys. Food chemistry, 101, 2, 695-703. https:// doi.org/10.1016/j.foodchem.2006.01.058.

2. Bergamo G., Sergalio S.K.T., Gonzaga L.V., Fett R., Costa A.C.O. 2019. Physicochemical characteristics of bracatinga honeydew honey and blossom honey produced in the state of Santa Catarina: An approach to honey differentiation. Food Research International, 116, 745-754. https://doi. org/10.1016/j.foodres.2018.09.007. 
3. Bogdanov S., Ruoff K., Persano-Oddo L. 2004. Physico-chemical methods for the characterisation of unifloral honeys: A review. Apidologie, 35, 4-17. doi: 10.1051/apido:2004047.

4. Dobre I., Georgescu I.A., Alexe P., Escuerdo O., Seijo M.C. 2012. Rheological behavior of different honey types from Romania. Food Research International, 49, 1, 126-132. https://doi.org/10.1016/j.foodres.2012.08.009.

5. Escuerdo O., Miguez M., Fernández-González M., Seijo M. 2013. Nutritional value and antioxidant activity of honeys produced in European Atlantic area. Food Chemistry, 138, 2-3, 851-856. https://doi.org/10.1016/j.foodchem.2012.11.015.

6. Escuredo O., Dobre I., Fernández-Gonzálezs M., Seijo M.C. 2014. Contribution of botanical origin and sugar composition of honeys on the crystallization phenomenon. Food Chemistry, 149, 84-90. https://doi. org/10.1016/j.foodchem.2013.10.097.

7. European Union. 2002. European Commission Council Directive 2001/110/EC of 20. December 2001, relating to honey. Official Journal of the European Communities, L10:47.https://eur-lex.europa.eu/legal- content/EN/TXT/PDF/?uri= CELEX: 32001L0110\&from=EN

8. Flores M.S.R., Escuerdo O., Seijo M.C. 2015. Assessment of physicochemical and antioxidant characteristics of Quercus pyrenaica honeydew honeys. Food Chemistry, 166, 101-106. https://doi.org/10.1016/j.foodchem.2014.06.005.

9. International Honey Commission Methods. 2009. Harmonised methods of the International Honey Commission Methods, Swiss Bee Research Centre, FAM, Liebefeld, Switzeland.

10. Kabbani D., Sepulcre F., Wedekind J. 2011. Ultrasound-assisted liquefaction of rosemary honey: Influence on rheology and crystal content. Journal of Food Engineering, 107, 2, 173-178. https://doi.org/10.1016/j.jfoodeng.2011.06.027.

11. Karabagias I.K., Badeka A.V., Kontakos S., Karabournioti S., Kontominas M.G. 2014. Botanical discrimination of Greek unifloral honeys with physico-and chemometric analyses. Food Chemistry, 165, 181-190. https://doi. org/10.1016/j.foodchem.2014.05.033.

12. Kirs E., Pall R., Martverk K., Laos K. 2011. Physicochemical and melissopalynological characterization of Estonian summer honeys. Procedia Food Science 1, 1, 616-624. https://doi.org/10.1016/j.profoo.2011.09.093.

13. Kivrak Ş., Kivrak I., Karababa E. 2017. Characterization of Turkish regarding of physicochemical properties, and their adulteration analysis. Food Science and Technology (Campinas), 37, 1, 80-89. http://dx.doi. org/10.1590/1678-457x.07916. 
14. Laos K., Kirs E., Pall R., Martverk K. 2011. The crystallization behaviour of Estonian honeys. Agronomy Research, 9, 427-432.

15. Lazarević K.B., Jovetić M.S., Tešić Ž.Lj. 2017. Physicochemical parameters as a tool for the assessment of origin of honey. Journal of AOAC International, 100, 4, 840-851. https://doi.org/10.5740/jaoacint.17-0143.

16. Megazyme Interantional Ireland. 2014. Diastase activity (a-Amylase) in honey, Assay procedure, T-AMZHY, 05/14, www.megazyme.com

17. Official Gazette RS. 2015. Rulebook on quality of honey and other bee products, No. 101.

18. Ouchemoukh S., Louaileche H., Schweitzer P. 2007. Physicochemical characteristics and pollen spectrum of some Algerian honeys. Food Control, 18, 1, 52-58. https://doi.org/10.1016/j.foodcont.2005.08.007.

19. Pasias I.N., Kiriakou I.K., Proestos, C. 2017. HMF and diastase activity in honeys: a fully validated approach and a chemometric analysis for identification of honey freshness and adulteration. Food Chemistry, 229, 425-431. https://dx.doi. org/10.1016/j.foodchem.2017.02.084.

20. Primorac Lj., Angelkov B., Mandić M., Kenjerić D., Nedeljko M., Flanjak I., Perl Pirički A., Arapceska M. 2009. Comparison of the Croatian and Macedonian honeydew honey. Journal of Central European Agriculture, $10,3,263-270$.

21. Saxena S., Gautam S., Sharma, A. 2010. Physical, biochemical and antioxidant properties of some Indian honeys. Food Chemistry, 118, 2, 391-397. https://doi.org/10.1016/j.foodchem.2009.05.001.

22. Seijo M.C., Escuerdo O., Rodríguez-Flores M. 2019. Physicochemical properties and pollen profile of oak honeydew and evergreen oak honeydew honeys from Spain: A comparative study. Foods, 8, 4, 126. https://doi. org/10.3390/foods8040126.

23. Sergalio K.T.S., Silva B., Bergamo G., Brugnerotto P., Gonzaga L. V., Fett R., Costa A.C.O. 2019. An overview of physicochemical characteristics and health-promoting properties of honeydew honey. Food Research International, 119, 44-60. https://doi.org/10.1016/j.foodres.2019.01.028.

24. Silva B., Gonzaga L.V., Fett R., Costa A.C.O. 2018. Simplex-centroid design and Derringers desirability function approach for simultaneous separation of phenolic compounds from Mimosa scabrella Bentham honeydew honeys by HPLC-DAD. Journal of Chromatography A, 1585, 182-191. https://doi. org/10.1016/j.chroma.2018.11.072.

25. Sousa J.M.B., Soza L.E., Marques G., Benassi M.T., Gullon B., Pintado M.M. 2016. Sugar profile, physicochemical and sensory aspects of monofloral honeys produced by different stingless bee species in Brazilian semi- 
arid region. LWT - Food Science and Technology, 65, 645-651. https://doi. org/10.1016/j.lwt.2015.08.058.

26. Valdés-Silverio L.A., Iturralde G., García-Tenesaca M., Paredes-Moreta J., Narváez-Narváez D.A., Rojas-Carrillo M., Tejera E., Beltrán-Ayala P., Giampieri F., Alvarez-Suarez J.M. 2018. Physicochemical parameters, chemical composition, antioxidant capacity, microbial contamination and antimicrobial activity of Eucalyptus honey from the Andean region of Ecuador. Journal of Apicultural Research, 57(3), 382-394. https://doi.org/10.10 80/00218839.2018.1426349.

27. Vasić V., Gašić U., Stanković D., Lušić D., Vukić-Lušić D., Milojković-Opsenica D., Tešić Ž., Trifković J. 2019. Towards better quality criteria of European honeydew honey: phenolic profile and antioxidant capacity. Food Chemistry, 274, 629-641. https://doi.org/10.1016/j.foodchem.2018.09.045.

28. Venir E., Spaziani M., Maltini E. 2010. Crystallization in "Tarassaco" Italian honey studied by DSC. Food Chemistry, 122, 2, 410-415. https://doi. org/10.1016/j.foodchem.2009.04.012.

29. Yadata D. 2014. Detection of the electrical conductivity and acidity of honey from different areas of Tepi. Food Science and Technology, 2, 5, 5963. DOI: $10.13189 /$ fst.2014.020501.

30. Živkov Baloš M., Jakšić S., Mihaljev Ž., Popov N., Ljubojević Pelić D., Vidaković S. 2019a. Sugar profile of honeys from Serbia. Abstract book, Second International Congress on Hygiene and Preventive Medicine "Challenges and Public Health Interventions", Novi Sad, 10-13. April 2018, Faculty of Medicine, University of Novi Sad, 108-109, ISBN 978-86-7197-577-3.

31. Živkov Baloš M., Jakšić S., Popov N., Mihaljev Ž., Ljubojević Pelić D. 2019b. Comparative study of water content in honey produced in different years. Archives of Veterinary Medicine, 12, 1, 43-53.

32. Živkov Baloš M., Popov N., Vidaković S., Ljubojević Pelić D., Pelić M., Mihaljev Ž., Jakšić S. 2018. Electrical conductivity and acidity of honey. Archives of Veterinary Medicine, 11, 1, 91-101.

Submitted: 08.10.2019.

Accepted: 02.12.2019. 